\title{
Burkholderia thailandensis: the Main Bacteria Biodegrading Fipronil in Fertilized Soil with Assessment by a QuEChERS/GC-MS Method
}

\author{
Luciana T. D. Cappelini, ${ }^{a}$ Juliana V. Alberice, ${ }^{a}$ Patrícia F. M. Eugênio, ${ }^{a}$ Eloisa Pozzi, ${ }^{b}$ \\ Ana Carolina Urbaczek, ${ }^{a}$ Lia G. R. Diniz, ${ }^{a}$ Elma N. V. M. Carrilho, ${ }^{c}$ Emanuel Carrilho ${ }^{* a}$ \\ and Eny M. Vieira ${ }^{a}$ \\ anstituto de Química de São Carlos, Universidade de São Paulo, \\ Avenida Trabalhador São-Carlense, 400, 13566-590 São Carlos-SP, Brazil \\ ${ }^{b}$ Departamento de Hidráulica e Saneamento, Escola de Engenharia de São Carlos, \\ Universidade de São Paulo, Avenida Trabalhador São-Carlense, 400, \\ 13560-970 São Carlos-SP, Brazil \\ 'Departamento de Ciências da Natureza Matemática e Educação, \\ Universidade Federal de São Carlos, Rodovia Anhanguera, km 174, SP-330, \\ 13600-970 Araras-SP, Brazil
}

\begin{abstract}
Due to the expansion of sugarcane crops and the high costs of agricultural inputs, an alternative for fertilization of the soil is the use of humic substances (HS) because they improve its physical-chemical properties. The objective of this study was to assess the biological degradation of fipronil in soil supplemented with HS. For determination of fipronil and its metabolites, we validated a quick, easy, cheap, effective, rugged, and safe gas chromatography-mass spectrometry (QuEChERS/GC-MS) method, which yielded detection and quantification limits of 15.0 and $62.5 \mathrm{ng} \mathrm{g}^{-1}$, respectively. The method presented linearity of 0.99 , precision between 1.5 and $10.9 \%$, while the recovery ranged from 78 to $98 \%$, with precision (relative standard deviation (RSD)) $<5 \%$. The strain $B$. thailandensis of Burkholderia sp. grew under typical conditions for degradation of fipronil. Eight treatments assessed the degradation by B. thailandensis in the presence of HS. The metabolites produced in the experiment, although detected, could not be quantified because they were below the limit of quantification of the method. Our results showed that $B$. thailandensis has the potential to degrade fipronil, and that HS is not toxic to the microbiota, and does not inactivate fipronil.
\end{abstract}

Keywords: sugarcane culture, QuEChERS, GC-MS, metabolites, phylogenetics

\section{Introduction}

Sugarcane is a tropical plant belonging to the family of grasses, widely grown as a hybrid, and mainly found in tropical countries. The flowering of this crop begins in autumn and the harvest takes place in the dry season, for a period of three to six months. ${ }^{1}$ In Brazil, the cultivation of sugarcane began in São Paulo State around 1522, and currently this region is the world's largest producer of this culture. ${ }^{2}$ In the 2015/2016 harvest, the sugarcane cultivated area in Brazil was estimated to be approximately 8.95 million of hectares and its total production was estimated to be 655 million tons, comprising an increase of $3.2 \%$ in comparison to the crops of 2014/2015. ${ }^{2}$

*e-mail: emanuel@iqsc.usp.br
Due to the expansion of sugarcane production and the high costs of farming, new ways of soil management are devised to increase productivity and promote environmental quality. With this purpose, one can add organic material in soil because, according to recent concepts, the efficient handling of soil organic matter is an effective method of improving quality and, consequently, agricultural productivity. ${ }^{3}$

Around $80 \%$ of the soil organic matter consist of humic substances (HS), ${ }^{4,5}$ which brings important benefits to agriculture, such as nutrient supply, stability of soil aggregates, increase in water infiltration, and the retention of water, heat, and cations. In addition, HS can complex or chelate toxic substances, and such characteristics have drawn attention of many researchers due to the large increase of its use as fertilizer in agriculture, which in 
fact, turns out to be toxic to microorganisms. ${ }^{6-9}$ It is worth mentioning the use of agricultural inputs in sugarcane production is extensive, and among them fipronil stands out.

Fipronil is a phenylpyrazole insecticide registered in the USA since $1996,{ }^{10}$ and is directly applied over the sugarcane crop, or in the planting furrow, to form a barrier against insects. The half-life of this compound varies between 6 to 10 months, depending on the type of soil in which it is applied..$^{10}$ The degradation of fipronil forms fipronil sulfone, fipronil sulfide (biotic and abiotic oxidation), and fipronil desulfinyl (photolysis). ${ }^{11}$ Biotic degradation is the most significant route for the degradation of fipronil in the soil (Figure 1). ${ }^{12}$

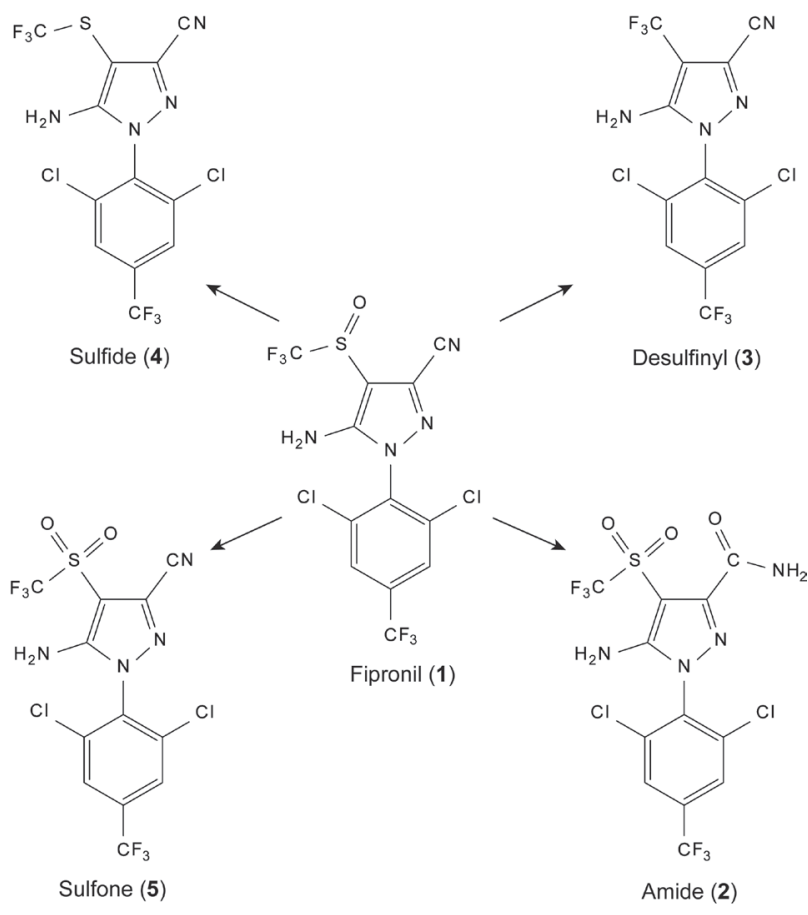

Figure 1. Chemical structures of fipronil (1) and their degradation products, amide (2), desulfinyl (3), sulfide (4), and sulfone (5).

Soil is a quite unknown, complex, and heterogeneous ecosystem capable of housing an immense biological diversity. It is estimated that $99 \%$ of the bacteria species present in soil are viable but not cultivable, i.e., they cannot be extracted, isolated, and cultured using traditional laboratory techniques. ${ }^{13}$ Therefore, molecular biology is an important tool in the analysis of soil microbial communities. The extraction of microbial DNA from soil is the most difficult stage of the whole process; it presents limitations, mainly due to the presence of contaminants, such as humic acids. ${ }^{14}$

Due to the growing interest in identifying soil microorganisms that could lead to fipronil degradation whether or not using HS in agriculture, this study aimed at: $(i)$ identifying bacteria that can use fipronil as a carbon source from a soil cultivated with sugarcane by using molecular biology techniques; (ii) assessing the biological degradation of fipronil in the presence of HS using a quick, easy, cheap, effective, rugged, and safe gas chromatography-mass spectrometry (QuEChERS/GC-MS) method as analytical approach.

\section{Experimental}

\section{Materials}

Analytical standards of fipronil, fipronil sulfide, and fipronil sulfone were obtained from AccuStandard (New Haven, CT, USA), with $99 \%$ purity. The chromatographic conditions were defined using analytical standards prepared from $60 \mathrm{mg} \mathrm{L}^{-1}$ stock solutions in ethyl acetate PA (Merck, Darmstadt, Germany). Methanol, acetone, and hexane PA (Merck, Darmstadt, Germany) were used for soil clean up.

\section{Methods}

\section{Collection of soil samples and mineral analysis}

The soil samples were collected from an area of sugarcane plantation, which had a long-term track-record of use of fipronil, in the city of São Carlos (São Paulo, Brazil). First, we delimited the area of $30 \times 40 \mathrm{~m}$ on a map and then reproduced back in the field. This dimension was chosen due to the uniformity of the area under study. The sampling was carried out in a mid-spring and sunny day $\left(33^{\circ} \mathrm{C}\right)$, after a 15 -day period with no rainfall.

Five $200 \mathrm{~g}$ samples of entisol soil in the $10-20 \mathrm{~cm}$ horizon were collected using an auger. These samples were placed into a bucket and then homogenized, becoming a single sample of approximately $1 \mathrm{~kg}$. This procedure was repeated five times and the samples were packed in dark plastic bag and stored at $-20{ }^{\circ} \mathrm{C}$.

After clean up with methanol, ${ }^{15}$ the soil was autoclaved to eliminate any microorganisms and, later, it was sent to a certified laboratory to provide the mineral content using standard methods for soil analysis.

\section{Bacteria cultivation and DNA extraction}

The collected soil was used as an inoculum for the isolation of microorganisms capable of using fipronil as carbon source. Ten grams of this soil were transferred to a tube containing $90 \mathrm{~mL}$ of sterile buffered water ( $\mathrm{pH} 7)$. The system was kept under stirring for $1 \mathrm{~h}$ at $30^{\circ} \mathrm{C}$. Afterwards, $9 \mathrm{~mL}$ of the supernatant were transferred to an Erlenmeyer containing $81 \mathrm{~mL}$ of a solution of $1.66 \mathrm{mg} \mathrm{L}^{-1}$ of fipronil, and this mixture was kept in an incubator at $30^{\circ} \mathrm{C}$ for $48 \mathrm{~h}$. 
Bacteria were cultivated in the presence of fipronil in order to select only the ones capable of living in such conditions.

Bacterial DNA extraction was performed using a modified Griffith's method. ${ }^{16}$ The solution containing the bacteria was divided into two $45 \mathrm{~mL}$ aliquots and transferred to Falcon tubes of $50 \mathrm{~mL}$. The solutions containing the bacteria were centrifuged at $6,000 \mathrm{rpm}$ for $10 \mathrm{~min}$, and the supernatant was discarded. The resulting pellets were washed with $5 \mathrm{~mL}$ of PBS (phosphate-buffered saline) buffer, stirred and centrifuged at $6,000 \mathrm{rpm}$ for $10 \mathrm{~min}$ at $4{ }^{\circ} \mathrm{C}$, and the supernatant was discarded. Extracts were collected in a single tube, mixed with $0.5 \mathrm{~g}$ of glass beads, $1 \mathrm{~mL}$ of PBS, $1 \mathrm{~mL}$ of buffered phenol ( $\mathrm{pH} 8$ ), and $1 \mathrm{~mL}$ of chloroform, under refrigeration $\left(4^{\circ} \mathrm{C}\right)$. The mixture was homogenized and then centrifuged at $6,000 \mathrm{rpm}$ for $10 \mathrm{~min}$ at $4{ }^{\circ} \mathrm{C}$. Aliquots of $800 \mu \mathrm{L}$ of the supernatant and $800 \mu \mathrm{L}$ of phenol were transferred to an Eppendorf. This mixture was stirred to form an emulsion and centrifuged at $6,000 \mathrm{rpm}$ for $10 \mathrm{~min}$ at $4{ }^{\circ} \mathrm{C}$. Thereafter, approximately $600 \mu \mathrm{L}$ of the supernatant were transferred into a new Eppendorf and an equal volume of chloroform was added. They were mixed to form an emulsion and centrifuged again at $6,000 \mathrm{rpm}$ for $10 \mathrm{~min}$ at $4{ }^{\circ} \mathrm{C}$. Approximately $400 \mu \mathrm{L}$ of the supernatant were transferred to an Eppendorf and the same volume of chloroform was added. The solution was stirred and centrifuged at 6,000 rpm for $10 \mathrm{~min}$ at $4{ }^{\circ} \mathrm{C}$. Approximately $100 \mu \mathrm{L}$ of the supernatant containing bacterial DNA were transferred to an Eppendorf and stored at $-20^{\circ} \mathrm{C}$. Absorbance measures of the DNA solution $(230,260$, and $280 \mathrm{~nm}$ ) were performed using a Gene Quant spectrophotometer (Amersham Bioscience, Little Chalfont, UK) for quantification and determination of purity. The purity of the DNA sample was calculated from the rations in absorbance at the three selected wavelengths: $\mathrm{A}_{260} / \mathrm{A}_{230}$ and $\mathrm{A}_{260} / \mathrm{A}_{280}$ ratios.

For DNA analysis, a $0.8 \%$ agarose gel received $5 \mu \mathrm{L}$ of the DNA-containing solution and $2 \mu \mathrm{L}$ of Green Blue dye in each lane, and the electrophoresis was carried out at $70 \mathrm{~V}$ and $300 \mathrm{~mA}$ for $40 \mathrm{~min}$ in a Bio-Rad cube (Hercules, CA, USA). The DNA bands were observed and photographed with an Eagle Eye ${ }^{\circledR}$ II transilluminator (Amersham Bioscience, Little Chalfont, UK) under UV illumination. A molecular weight marker of 1,000 bp (Invitrogen $^{\circledR}$, Carlsbad, CA, USA) was used.

\section{DNA amplification}

Polymerase chain reaction (PCR) amplification of the DNA extracted from soil was performed flanking the conserved region of $16 \mathrm{~S}$ rDNA using universal primer for the Bacteria domain 27F (5' - AGAGTTTGATCCTGGCTCAG - 3') / 1100R (5' - AGGGTTGCGCTCGTTG - 3') ${ }^{17}$ and using the reagent kit from Invitrogen ${ }^{\circledR}$ as follows: $2.5 \mu \mathrm{L}$ of
PCR reaction buffer $10 \times, 0.75 \mu \mathrm{L}$ of $50 \mathrm{mmol} \mathrm{MgCl}_{2} \mathrm{~L}^{-1}$, $0.5 \mathrm{~mL}$ of $2.0 \mathrm{mmol} \mathrm{dNTPs} \mathrm{L}^{-1}, 0.5 \mathrm{~mL}$ of each primer, $0.25 \mu \mathrm{L}$ of Taq DNA polymerase $\left(5 \mu \mathrm{g} \mu \mathrm{L}^{-1}\right)$ and $2.0 \mu \mathrm{L}$ of DNA. The volume of each solution was completed to $50 \mu \mathrm{L}$ with sterile water free from organics. A thermocycler Gene Amp PCR System 2400 (PerkinElmer Cetus, Norwalk, CT, USA) was used. The cycling conditions for DNA amplification were: initial denaturation at $94^{\circ} \mathrm{C}$ for $2 \mathrm{~min}$, 10 cycles of $1 \mathrm{~min}$ denaturation at $94{ }^{\circ} \mathrm{C}, 30 \mathrm{~s}$ annealing at $69{ }^{\circ} \mathrm{C}$, and $3 \mathrm{~min}$ at $72{ }^{\circ} \mathrm{C}$ for extension, followed by another 10 cycles of $1 \mathrm{~min}$ denaturation at $94{ }^{\circ} \mathrm{C}, 30 \mathrm{~s}$ annealing at $63{ }^{\circ} \mathrm{C}$, and $3 \mathrm{~min}$ at $72{ }^{\circ} \mathrm{C}$ for extension, and a final cooling to $4{ }^{\circ} \mathrm{C} .{ }^{17}$

In order to assess the reaction efficiency, the PCR product was subjected to electrophoresis in a $1.4 \%$ agarose gel at $90 \mathrm{~V}$ and $300 \mathrm{~mA}$ for $40 \mathrm{~min}$ in a Bio-Rad ${ }^{\circledR}$ cube. The bands were photographed in a transilluminator Eagle Eye $^{\circledR}$ II with ultraviolet illumination. For this procedure, a molecular marker (Invitrogen ${ }^{\circledR}$ ) of 1,000 bp was used.

\section{Bacteria cloning}

PCR products were adenylated by pipetting $3 \mu \mathrm{L}$ of purified DNA, $1 \mu \mathrm{L}$ of buffer containing $\mathrm{MgCl}_{2}, 1 \mu \mathrm{L}$ of dATP, $1 \mu \mathrm{L}$ of Taq DNA polymerase, and $4 \mu \mathrm{L}$ of sterile ultra-pure water. The material was incubated at $70{ }^{\circ} \mathrm{C}$ for $30 \mathrm{~min}$.

Adenylated PCR products were cloned into plasmid pGEM Easy Vector System I, as specified by the manufacturer (Promega ${ }^{\circledR}$, Madison, WI, USA). The binding of the adenylated PCR products to the $\mathrm{PGEM}$ vector was obtained by the addition of the following components, as follows: $5 \mu \mathrm{L}$ of $2 \times$ binding buffer, $1 \mu \mathrm{L}$ of pGEM vector, $2 \mu \mathrm{L}$ of the adenylated PCR product, $1 \mu \mathrm{L}$ of T4 ligase, and $1 \mu \mathrm{L}$ of sterile ultra-pure water. These reagents were mixed and incubated for $1 \mathrm{~h}$ at room temperature.

Escherichia coli DH5 $\alpha$ competent cells were transformed with the recombinant $\mathrm{pGEM}$ vector by thermal shock at $42^{\circ} \mathrm{C}$ for $50 \mathrm{~s}$ and, subsequently, at $4{ }^{\circ} \mathrm{C}$ for $2 \mathrm{~min}$. Then, $200 \mu \mathrm{L}$ of LB (Luria-Bertani) medium (pH 6.5-7.0) were added at room temperature and the mixture was incubated for $12 \mathrm{~h}$ at $4{ }^{\circ} \mathrm{C}$.

The transformed bacteria $(100 \mu \mathrm{L})$ were plated in $\mathrm{LB}$ agar medium with $28 \mu \mathrm{L}$ of ampicillin $(0.5 \mathrm{~g}$ in $10 \mathrm{~mL}$ of water), $47 \mu \mathrm{L}$ of isopropyl- $\beta$-D-thiogalactopyranoside (IPTG) $\left(23 \mathrm{mg} \mathrm{mL}^{-1}\right)$ and $64 \mu \mathrm{L}$ of X-Gal $\left(40 \mathrm{mg} \mathrm{mL}^{-1}\right)$ and incubated at $37^{\circ} \mathrm{C}$ for $12 \mathrm{~h}$. Then, the colonies, which received the insert, were picked out by hand and a PCR was performed for confirmation using the primers: M13 forward (5' - GTA AAA CGA CGG CCA G - 3') and M13 reverse (5' - CAGGGAACAGCTATGAC - 3'). The program used for amplification was: initial denaturation at $94{ }^{\circ} \mathrm{C}$ for 
$2 \mathrm{~min}, 25$ cycles of $60 \mathrm{~s}$ of denaturation at $94^{\circ} \mathrm{C}$ for $60 \mathrm{~s}$, annealing at $55^{\circ} \mathrm{C}$ and $60 \mathrm{~s}$ of extension at $72{ }^{\circ} \mathrm{C}$, with final extension for $7 \mathrm{~min}$ at $72{ }^{\circ} \mathrm{C}$, and cooling to $4{ }^{\circ} \mathrm{C}$. To prove the efficiency of cloning reactions, the sample was submitted to a $1.4 \%$ agarose gel electrophoresis.

\section{DNA sequencing}

The amplified material was sent to the sequencing company Macrogen, Seoul, Korea. A total of 96 clones were sequenced. The nucleotides were sequenced in the Eppendorf sequencer ABI 3730 XL (Berlin, Germany). Forward and reverse primers $27 \mathrm{~F}$ were used.

The sequencing data were aggregated and aligned using the DNASTAR software package (Lasergene sequence analysis). ${ }^{18}$ The sequences grouped into consensus (contigs) were assigned to operational taxonomic units (OTUs). After the alignment of at least $400 \mathrm{bp}$, this nucleotide sequences were compared to sequences of the electronic database NCBI-database approach for the phylogenetic identity (at least, $98 \%$ of similarity).

To build the phylogenetic tree we used the Neighbor Joining algorithm of the Molecular Evolutionary Genetics Analysis program (MEGA) version $5.5,{ }^{19}$ considering an evolutionary distance of 0.05 and the "bootstrap" analyses were based on 100 resampling.

\section{Analytical instrumentation}

Fipronil and its metabolites (fipronil sulfide and fipronil sulfone) were identified and quantified by gas chromatography coupled to a mass spectrometry (GC-MS) detector in the electron ionization (EI) mode, both from Shimadzu QP2010 (Kyoto, Japan), using the following chromatographic conditions: column DB 5 from Agilent (Santa Clara, CA, USA) $(30 \mathrm{~m} \times 0.25 \mathrm{~mm} \times 0.25 \mu \mathrm{m})$, injector and detector temperature of 280 and $270{ }^{\circ} \mathrm{C}$, respectively, flow rate of $1.3 \mathrm{~mL} \mathrm{~min}^{-1}$, split ratio of $1: 10$, and injection volume of $1 \mu \mathrm{L}$. The temperature program used was $80{ }^{\circ} \mathrm{C}$ ( $\left.1 \mathrm{~min}\right)$, increasing $25^{\circ} \mathrm{C} \mathrm{min}^{-1}$ up to $215^{\circ} \mathrm{C}$, followed by $3{ }^{\circ} \mathrm{C} \mathrm{min}^{-1}$ up to $250{ }^{\circ} \mathrm{C}$. Helium was used as the carrier gas at $60 \mathrm{kPa}$. The compounds were identified from the fragmentation ions $(70 \mathrm{eV})$ detected in the GC-MS spectra. Monitored ions were $\mathrm{m} / \mathrm{z}$ 351.00, 366.95 , and 382.95 for fipronil sulfide, fipronil, and fipronil sulfone, respectively, with retention times of 9.6, 9.8, and $11.3 \mathrm{~min}$, respectively, in an $18 \mathrm{~min}$ run.

\section{Preparation of the soil samples}

In order to assess the physicochemical properties of the soil, interfering components such as pesticides that could be present in the sample were eliminated. So, the soil was dried, macerated in a crucible, and sieved to a $2 \mathrm{~mm}$ mesh particle size to standardize the samples. Then, three samples of $10 \mathrm{~g}$ of this soil were transferred to Erlenmeyers, in which $40 \mathrm{~mL}$ of the following solvents were added to each of them: acetone:hexane (1:1 in volume), methanol, and ethyl acetate. Finally, they were sonicated for $1 \mathrm{~h}$.

After sonication, the extracts were filtered in qualitative filter paper (grammage of $250 \mathrm{~g} \mathrm{~m}^{-2}$ and $33 \mathrm{~cm}$ of diameter) and allowed to dry on a watch glass at room temperature. The most efficient solvent for this purpose was methanol (results from optimization not shown).

\section{QuEChERS method}

For the extraction of fipronil, fipronil sulfide, and fipronil sulfone from soil we used a modified QuEChERS method, ${ }^{20}$ in which the extracting solvent was ethyl acetate instead of acetonitrile. The complete description of the experimental procedure and the validation data for the method is presented in the Supplementary Information section (SI).

\section{Replication of the bacteria}

After identifying the microorganisms obtained from DNA extraction of the soil cultivated with sugarcane, a pure strain of the organism in study (Burkholderia thailandensis) was acquired from the Brazilian Collection of Microorganisms for the Environment and Industry (Campinas, Brazil). We chose this microorganism because it has shown evidences to biodegrade fipronil under the experimental conditions tested.

The microorganism was replicated in LB medium at $30{ }^{\circ} \mathrm{C}$ and the growth of the culture monitored by successive measurements using a Hitachi Z-5000 spectrophotometer (Tokyo, Japan) at $460 \mathrm{~nm}$. When the absorbance of the culture reached 0.485 (200 colony forming unit (CFU) $\mathrm{mL}^{-1}$ ) the microorganism was inoculated in a tube containing the soil under study. This culture was directly used to study the degradation of fipronil.

\section{Evaluation of fipronil degradation in soil containing HS}

Eight conditions were established to assess the microbial degradation of fipronil. For all treatments, $10 \mathrm{~g}$ of pre-cleaned and sterilized soil and $2.5 \mathrm{~mL}$ in the concentration of $2.5 \mathrm{mg} \mathrm{L}^{-1}(6.25 \mu \mathrm{g})$ of fipronil were used in the experimental design shown in Figure 2. In the treatments No. 1 and No. 2, 1 and $2 \mathrm{~mL}$ of the medium containing microorganisms (200 CFU mL $\left.\mathrm{mL}^{-1}\right)$ were added 
to the soil contaminated with fipronil, respectively. In treatments $\mathrm{A}, \mathrm{B}$, and $\mathrm{C}, 0.03,1.0$, and $1.5 \mathrm{~g}$ of $\mathrm{HS}$, respectively, were added to soils containing each of the two levels of microorganism load (treatment No. 1 received $200 \mathrm{CFU}$ and treatment No. 2 received $400 \mathrm{CFU}$ of $B$. thailandensis, respectively).

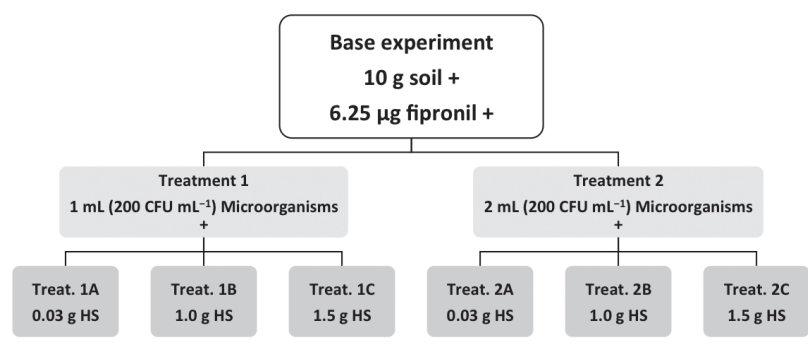

Figure 2. Organizational chart of the experiment design for degradation of $6.25 \mu \mathrm{g}$ of fipronil added to $10 \mathrm{~g}$ of soil, with $1 \mathrm{~mL}(200 \mathrm{CFU})$ and $2 \mathrm{~mL} \times 200 \mathrm{CFU} \mathrm{mL} \mathrm{m}^{-1}$ (400 CFU) of total load of the bacteria, at three levels of humic substances $(0.03,1.0$, and $1.5 \mathrm{~g})$.

The HS was previously sterilized by irradiation on a GAMMABEAN 650 (Nordion, Canada) (source cobalt ${ }^{60} \mathrm{Co}$, with a gamma-ray dose of $14.5 \mathrm{kGy}$ ) to eliminate microorganisms that could influence the experiment. The entire experiment was performed in a Thermolab (Maharashtra, India) incubator at $30^{\circ} \mathrm{C}$, protected from light, and with the tubes lids slightly open. The treatments were analyzed every $48 \mathrm{~h}$ for 60 days, in triplicate.

The concentration of fipronil solution $\left(2.5 \mathrm{mg} \mathrm{L}^{-1}\right)$ added to the soil was defined according to the values obtained from the analytical curve in the QuEChERS/GC-MS method, which was near the upper limit of the dynamic range tested (see SI section). Extracting the analyte and its metabolites from soil on a time-lapse experiment assessed the degradation kinetics of fipronil by bacteria.

\section{Results and Discussion}

\section{Extraction of DNA from soil}

The methods used for the cultivation of microorganisms presented in the soil and the posterior DNA extraction from soil were efficient because the absorbance ratios obtained $\left(\mathrm{A}_{260} / \mathrm{A}_{230}=2.49, \mathrm{~A}_{260} / \mathrm{A}_{280}=2.03\right)$ were in agreement with other reports; ${ }^{21}$ the $\mathrm{A}_{260 / 230}$ ratio should be greater or equal to 1.7 and the $\mathrm{A}_{260 / 280}$ ratio must be equal to or greater than 2.0. These ratios are indicators of the humic acids and proteins contents present in the extracted DNA.

The concentration of DNA extracted from soil was $26.4 \mathrm{ng} \mathrm{L}^{-1}$ and it was possible to visualize the bands in a $0.8 \%$ agarose gel. After performing the PCR, a $1.4 \%$ agarose gel was made, and the amplified regions could be observed. The results of the phylogenetic affiliation generated for the bacteria related to the cloned DNA can be seen in Figure 3.

The most frequent microorganism among the 96 sequenced clones is from the Clostridium genus, which is represented in the phylogenetic tree by S1 (49 clones). This genus consists of anaerobic bacteria, but some of them can be microaerophilic. Their main characteristic is the production of spores, which makes them resistant to adverse conditions, such as temperature variation, humidity, and other factors. In the environment, these bacteria may be present in soil and water. ${ }^{22}$

Several factors may contribute to the presence of Clostridium species in soil: seasonality, ${ }^{23}$ soil type, ${ }^{24}$ stagnant (accumulated) water, ${ }^{25}$ presence of inhibitors of their enzymatic activity, microorganisms, ${ }^{26} \mathrm{etc}$. Moreover, according to the literature, affiliated bacteria with genus Clostridium may be present in sites polluted with hydrocarbons; ${ }^{27}$ they are also tolerant to acid mine drainage systems, ${ }^{28}$ and resistant to butanol. ${ }^{29}$

Another microorganism found in the soil under study was Bdellovibrio bacteriovorus (2 clones), represented by $\mathrm{S} 3$, a small gram-negative bacterium, comma-shaped, and with the habit of preying on other bacteria, using the cytoplasmic components of their hosts as nutrients. It can be found in living organisms, in soil and water (seawater also), and it is only able to multiply itself within other bacteria. ${ }^{30}$ According to the literature, ${ }^{31}$ this bacterium was found in the Bristol Channel in Cardiff, England, where, at some points, contamination by the disposal of domestic sewage is found.

For the bacteria Flavisolibacter sp., 19 clones were found, however, a bacteroid belonging to the Chitinophagaceae family is not an easily found organism. According to the literature, their gender was discovered in soils with cultivation of ginseng, Korea ${ }^{32}$ and in several water samples in Southern Sweden. ${ }^{33}$

As for Burkholderia sp., 20 clones were found, which was an interesting discovery. These bacteria comprise more than 60 species isolated from different ecological niches, including: soil, plants, water, and other animal species. ${ }^{34}$ Studies in soil and groundwater have demonstrated the involvement of Burkholderia sp. in the degradation of chlorinated compounds. This bacterium has been isolated from contaminated sites and also has shown active results in degradation tests in microcosmos. ${ }^{35,36}$ Moreover, this genre is responsible for the degradation of chrysene. ${ }^{37}$ Burkholderia sp. isolated from sites contaminated with dinitrotoluene (DNT) demonstrated that this species is able to grow using nitrogen for metabolism and 2,4-DNT as a carbon source. ${ }^{38}$ 


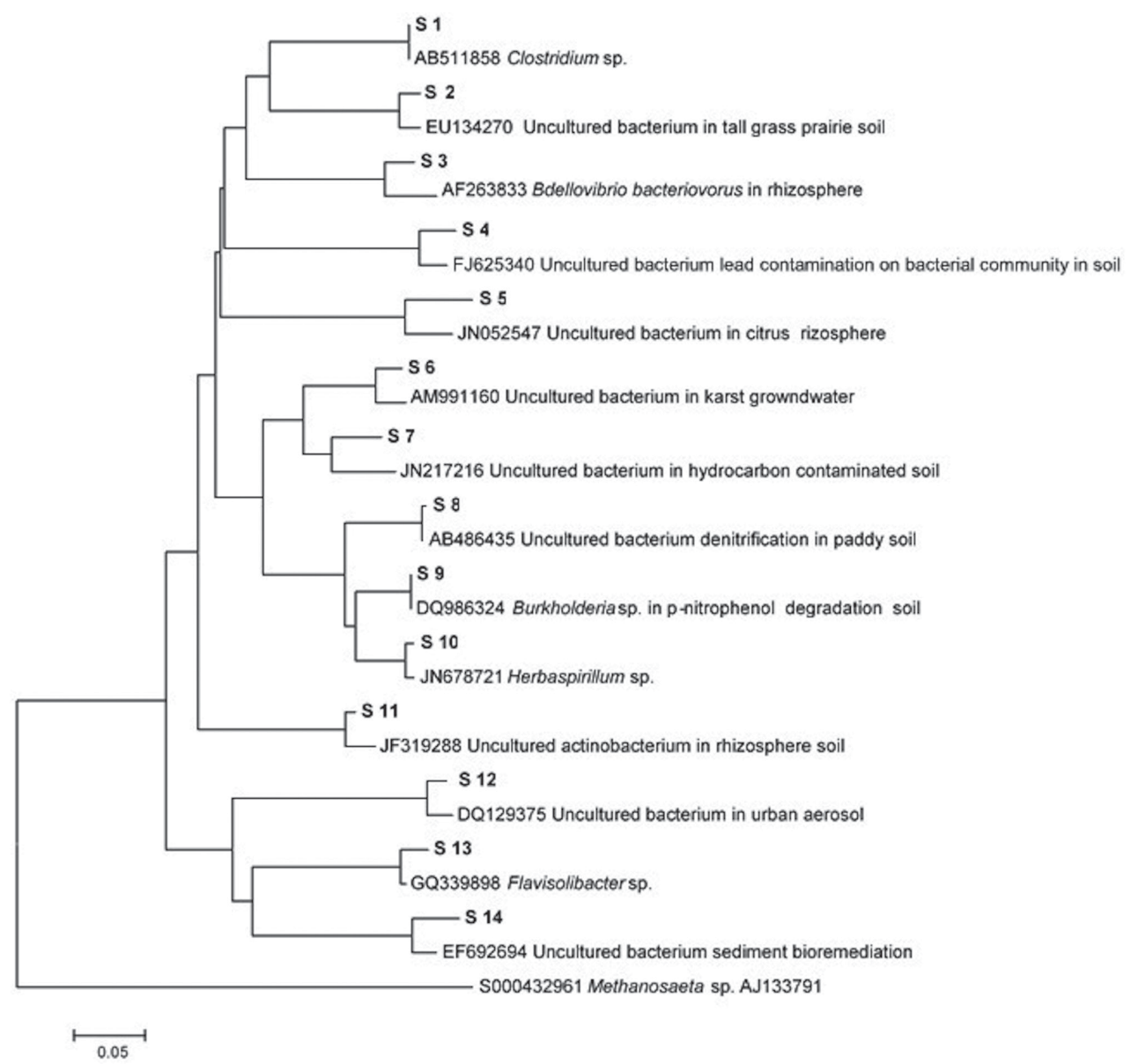

Figure 3. Phylogenetic tree, resulting from cloning and sequencing of bacterial DNA extracted from soil (bacteria capable of using fipronil as a carbon source). A total of 96 clones were sequenced and aligned.

The bacteria Clostridium sp. and Burkholderia sp. are the most common to be found in the soil, despite that oftentimes the Clostridium species in the soil can be in the spore form because there are correct conditions for its development. Also, species of Clostridium found in the soil can be pathogenic as Clostridium botulinum. In laboratory conditions these characteristics can bring problems to the study and also cause contamination to laboratory co-workers. Only two clones were found in the Bdellovibrio bacteriovorus, what suggests that fipronil may have caused damage to its development. Flavisolibacter sp. is already a bacteroid that needs to be close to the root system of a plant to be developed, so as the experiment did not use cultivation, this organism would not be an interesting genus to be evaluated.

We chose to work with Burkholderia sp. because we have successfully isolated it from a soil used in cultivation of sugarcane, which was able to grow in a fipronilcontaining medium. Thus, we believed Burkholderia sp. could use this pesticide as a carbon source and then we carried out further experiments in order to evaluate its behavior while in the presence of fipronil pesticide.
Validation of the QuEChERS/GC-MS method for determining fipronil, fipronil sulfide, and fipronil sulfone in soil

In order to evaluate the efficiency of the solvents used in the cleaning step for the validation of the method using QuEChERS, three solvents were tested: acetone:hexane (1:1), methanol, and ethyl acetate. The three solvents were efficient in soil clean up, but we chose methanol for this procedure because it provided less interference in the chromatogram when analyzing fipronil and its metabolites. The parameters used for the method validation of the extraction method for fipronil, fipronil sulfide, and fipronil sulfone were robustness, linearity, limit of quantification (LOQ), limit of detection (LOD), and recovery. ${ }^{39,40}$

The method robustness was assessed by Youden's test ${ }^{41}$ using the retention times and areas of the chromatographic peaks. According to the statistical analysis performed (Student's $t$-test), it can be stated that the method is robust, with $95 \%$ of confidence, because there was no statistically significant difference between the means of the assessed figures. To assess the analytical conditions, 
the concentration of the standard solution was ten times greater than the desired final concentration added (see SI section for more details).

The extraction was then carried out using the QuEChERS method according to the conditions described above. Analytical curves were built using the extracts of the soil after the QuEChERS method application for evaluation of matrix effects. The analytical curves contained six points from solutions ( $2.5 \mathrm{~mL}$ each) of 0.25 to $2.75 \mathrm{mg} \mathrm{L}^{-1}$, which corresponded from 62.5 to $687 \mathrm{ng}$ added per gram of soil, and yielded correlation coefficients greater than 0.99 . LOD and LOQ of the method were calculated by sequential dilution of standards using the signal-to-noise ratio of three and ten times, respectively. The LOD of fipronil and its degradation products were $15.0 \mathrm{ng} \mathrm{g}^{-1}$; the LOQ to fipronil and fipronil sulfone were $62.5 \mathrm{ng} \mathrm{g}^{-1}$ and to fipronil sulfide was $30.0 \mathrm{ng} \mathrm{g}^{-1}$. The recovery of the method was evaluated adding the standards of fipronil and its metabolites to the blank extract. The values found were compared with the extracts where it was added the standards of known concentration in the samples and then subjected to the extraction method. Recoveries of the three compounds were approximately 80 and $95 \%$ at the lowest $\left(15.0 \mathrm{ng} \mathrm{g}^{-1}\right)$ and the highest $\left(687 \mathrm{ng} \mathrm{g}^{-1}\right)$ levels of the curve, respectively.

\section{Bacterial degradation of fipronil}

The objective of this study was to evaluate the degradation of fipronil by an organism extracted from the soil with long track record of cultivation of sugarcane, and that such plantation makes use of fipronil together with HS. From the sequencing data and the phylogenetic classifications of all bacteria surviving in such environment, we chose to investigate closely the action of Burkholderia thailandensis on the degradation of fipronil, whether or not in the presence of HS.

Setting up the experiment using fipronil and B. thailandensis, in two levels, in three different loads of HS allowed us to assess the biological degradation of the pesticide and to identify traces of two of its metabolites: fipronil sulfide and fipronil sulfone.

The treatments No. 1 and No. 2 contained fipronil, soil, and B. thailandensis in two loads, 1 and $2 \mathrm{~mL}$ of a solution of $200 \mathrm{CFU} \mathrm{mL} \mathrm{m}^{-1}$, respectively. These experiments aimed to assess the biological degradation of fipronil in the absence of HS, as well as to verify if different amounts of microorganisms would influence fipronil degradation.

From the chromatograms shown in Figure 4, it can be seen that the degradation of fipronil by $B$. thailandensis takes place, forming fipronil sulfone and fipronil sulfide in the absence of HS. The chromatogram (a) shows the lowest point in the analytical curve (LOQ), which used a $2.5 \mathrm{~mL}$ aliquot of the standard solution containing $0.25 \mathrm{mg} \mathrm{L}^{-1}$ of each compound added to the soil $(10 \mathrm{~g})$, then extracted by the QuEChERS/GC-MS method. The chromatogram (b) shows the extraction of fipronil (second, off the scale, peak) and two metabolites (sulfide, left, and sulfone, right) from treatment No. 2B after 8 weeks in the presence of $400 \mathrm{CFU}$ of $B$. thailandensis. Under these conditions, the two metabolites were detected but not quantified, as their peak areas were smaller than the LOQ (Figure 4a).

Furthermore, the volumes of LB medium ( 1 or $2 \mathrm{~mL}$ ) containing microorganisms added to the soil did not affect the degradation fipronil, i.e., no changes in the values of peak areas of the tested compounds were noticed. These data were confirmed by the analysis of variance (ANOVA) (peak areas were used for the calculation), which provided a calculated $F$ that is smaller than the $F$ tabulated ( $F$ critical), confirming that these values are not significant among themselves, with $95 \%$ confidence (Table 1). The degradation kinetics is associated to specific biotic and abiotic factors for each type of pesticide as its sorption occurs in the soil due to its physical properties. Such physical-chemical properties regulate the bioavailability of the chemicals and influences their degradation since it is known that only the pesticides present in the soil solution are available for microbial action. Therefore, different loads of microorganisms may not correlate directly to the extent of the degradation of xenobiotics. ${ }^{42,43}$

Similarly to No. 1 and No. 2, the treatments $1 \mathrm{~A}, 1 \mathrm{~B}$, and $1 \mathrm{C}$, and $2 \mathrm{~A}, 2 \mathrm{~B}$, and $2 \mathrm{C}$ also presented the formation of the metabolites of fipronil (fipronil sulfide and fipronil sulfone), but they could not be quantified by the QuEChERS/GC-MS method, because the concentration levels of these two compounds were below the LOQ.

These results demonstrate that Burkholderia thailandensis has the potential to degrade fipronil into fipronil sulfide and fipronil sulfone. Fipronil degradation products may be more toxic than the parent compound. In terms of toxicity, the order of increasing toxicity we find fipronil amide, fipronil, fipronil desulfinyl, fipronil sulfone, and the most toxic of the derivatives, fipronil sulfide. ${ }^{44,45}$

The presence of other microorganisms in the environment may potentiate the biological degradation of fipronil in the soil, contributing to the total activity. Also, physical factors such as insolation, temperature, or humidity, which were not controlled in this experiment, can also influence in the degradation of compounds.

In the literature, there are no reports on the degradation of fipronil by Burkholderia thailandensis. Some authors found this genre in contaminated $\operatorname{sites}^{34,35}$ and others noted that $B$. thailandensis is able to degrade hydrocarbons such 


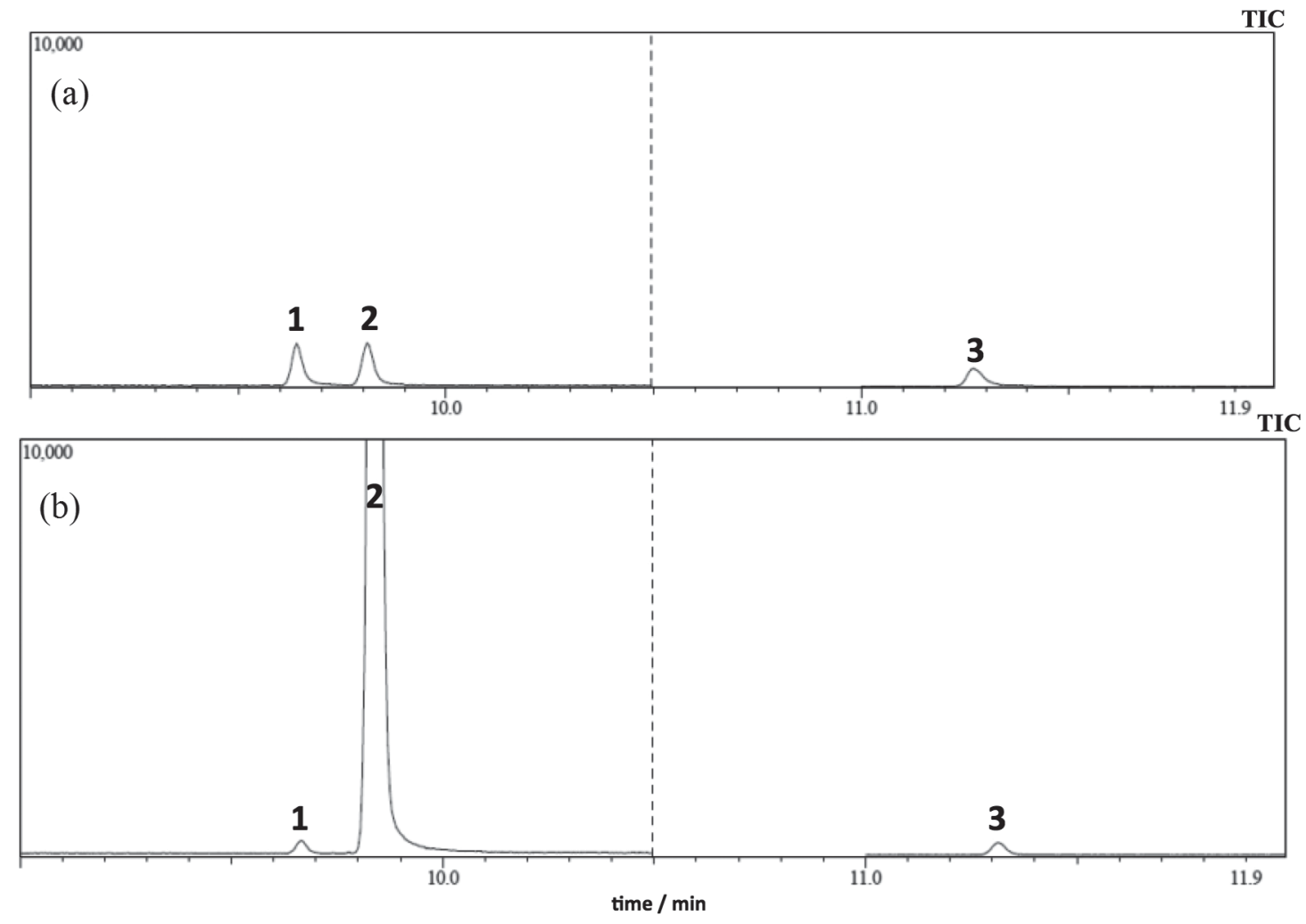

Figure 4. Chromatographic separation of fipronil and two main metabolites, upon degradation of fipronil in soil containing Burkholderia thailandensis

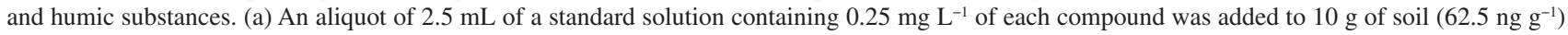
and extracted by the QuEChERS/GC-MS method; (b) extraction of the soil after 8 weeks of degradation of $625 \mathrm{ng}$ fipronil g ${ }^{-1}$ of soil (treatment 2B). Peak identities: 1: fipronil sulfide; 2: fipronil; 3: fipronil sulfone.

Table 1. Comparative data of analysis of variance (ANOVA) of fipronil, fipronil sulfide, and fipronil sulfone between treatments No. 1 and No. 2 , with $95 \%$ confidence

\begin{tabular}{lcc}
\hline & $F$ calculated & $F$ critical \\
\hline Fipronil & 0.7092 & 4.4138 \\
Fipronil sulfide & 0.9206 & 4.4138 \\
Fipronil sulfone & 0.9115 & 4.4138 \\
\hline
\end{tabular}

as chrysene. ${ }^{36}$ Thus, we can infer that this bacterium has the potential for biodegradation of organic pollutants.

Another interesting factor was that the treatments with different amounts of HS added to soil samples along with fipronil did not influence its degradation or inactivated this active ingredient, as farmers report that they need higher doses of fipronil when HS is present in the soil (personal communication in the field). This observation is extremely relevant for agriculture because, according to field reports, fipronil, when applied under the conditions of this study, could be found chelated to macromolecules present in HS and thus, inactivated or not bioavailable for degradation by microorganism. In other words, fipronil could be not fighting insects efficiently under such conditions if inactivated by humic substances.
Fipronil and its metabolites were detected in the same conditions of when we used only the bacterium (treatments No. 1 and No. 2), regardless the quantity of HS used. The statistical analysis of the chromatographic areas of the compounds by ANOVA between treatments 1A, 1B, 1C, $2 \mathrm{~A}, 2 \mathrm{~B}$, and $2 \mathrm{C}$, with $95 \%$, shows that calculated $F$ is smaller than the values of tabulated $F$, characterizing that as insignificant data (Table 2). That is, the formation of the metabolites, fipronil sulfide and fipronil sulfone, occurred, and that the initial fipronil concentration was the same in the treatments No. 1 and No. 2, indicated by the results of the $F$-test in Table 1 . This fact implies that this bacterium is responsible for the degradation of fipronil, and that the HS do not affect the efficiency of the product, neither alter the degradation rate of fipronil.

Table 2. Comparative data of analysis of variance (ANOVA) of peak areas for fipronil, fipronil sulfide, and fipronil sulfone between treatments $1 \mathrm{~A}$, $1 \mathrm{~B}, 1 \mathrm{C}, 2 \mathrm{~A}, 2 \mathrm{~B}$, and $2 \mathrm{C}$, with $95 \%$ confidence, to investigate the influence of humic substances in the degradation of fipronil

\begin{tabular}{lcc}
\hline & $F$ calculated & $F$ critical \\
\hline Fipronil & 0.9428 & 2.3860 \\
Fipronil sulfide & 0.9833 & 2.3860 \\
Fipronil sulfone & 0.7981 & 2.3860 \\
\hline
\end{tabular}


Furthermore, it can be observed that the degradation of fipronil by $B$. thailandensis occurred in the first few hours of the experiment because, after the formation of degradation products within $24 \mathrm{~h}$, the area of the compound remained constant until the end of the eighth week of evaluation (data not shown).

\section{Conclusions}

The results showed that the QuEChERS/GC-MS method was efficient to determine fipronil and its metabolites fipronil sulfide and fipronil sulfone from soil samples under the complex experimental conditions, which were based on the forms of application and concentration of fipronil and HS used in the field.

Thus, from the sampled soil, it was possible to identify bacteria with the potential for degradation of fipronil in its metabolites, revealing that, in the soil, it is possible to find microorganisms capable of degrading it into more toxic forms, which can be more aggressive than the initial active ingredient. The most frequent microorganism among the 96 sequenced clones was the Clostridium genus. From the organisms identified in collected soil samples, Burkholderia thailandensis bacteria were able to degrade fipronil in its metabolites, qualifying this microorganism as a potential agent for degradation of this pesticide.

The results also showed that HS added to the soil in different amounts did not affect the degradation or the inactivation of fipronil. However, the degradation of this molecule by $B$. thailandensis occurred within the first $24 \mathrm{~h}$ of the test and that, after the formation of degradation products, the levels of fipronil remained constant to the end of the eighth-week period evaluated.

The addition of organic matter in the soil did not directly alter the activity time of fipronil, however, such organicrich materials (HS, vinasse, filter cake, etc.) modify the physical-, chemical, and microbiological factors of the soil that interfere in the time of activity of this compound and can define its route of degradation.

\section{Supplementary Information}

Supplementary information is available free of charge at http://jbcs.sbq.org.br as PDF file.

\section{Acknowledgments}

This study was financially supported by the Brazilian funding agency CAPES (Coordenação de Aperfeiçoamento de Pessoal de Nível Superior). E. C. is member of the National Institute of Science and Technology in Bioanalytics (INCTBio).

\section{References}

1. Shrivastava, B.; Singh, Y.; Tiwari, S.; Sapre, S.; Indian. Res. J. Genet. \& Biotech. 2014, 6, 319.

2. http://www.conab.gov.br/OlalaCMS/uploads/ arquivos/16_01_12_09_00_46_boletim_graos_janeiro_2016. pdf, accessed in March 2018.

3. https://www.nrcs.usda.gov/wps/portal/nrcs/detail/soils/ ref/?cid=nrcs142p2_054242, accessed in March 2018.

4. Steverson, F. J.; Humus Chemistry: Genesis, Composition, Reaction, $2^{\text {nd }}$ ed.; John Willey: New York, NY, 1994.

5. Moreira, F. M. S.; Siqueira, J. O.; Microbiologia e Bioquímica do Solo, $2^{\mathrm{a}}$ ed.; UFLA: Lavras, Brazil, 2006.

6. Liu, P.; Moreno, J. M.; Song, P.; Hoover, E.; Harder, M. K.; Sustainability 2016, 8, 859.

7. Canellas, L. P.; Olivares, F. L.; Chem. Biol. Technol. Agric. 2014, 1, DOI: 10.1186/2196-5641-1-3.

8. Bayer, C.; Mielniczuk, J. In Fundamentos de Matéria Orgânica do Solo: Ecossistemas Tropicais e Subtropicais; Santos, G. A.; Silva, L. S.; Canellas, L. P.; Camargo, F. A. O., eds.; Metrópole: Porto Alegre, Brazil, 2008, p. 7.

9. Oliveira, M. F. In Plantas Daninhas e Seu Manejo; Oliveira Junior, R. S.; Constantin, J., eds.; Ed. Agropecuária: Guaíba, Brazil, 2001, p. 315.

10. Gunasekara, A. S.; Troung, T.; Environmental Fate of Fipronil; Environmental Monitoring Branch, Department of Pesticide Regulation, California Environmental Protection Agency: Sacramento, CA, USA, 2007.

11. Masutti, C. S. M.; Mermut, A. R.; J. Environ. Sci. Health, Part B 2007, 42, 33.

12. Vílchez, J. L.; Prieto, A.; Araújo, L.; Navalón, A.; J. Chromatogr. A 2001, 919, 215.

13. Geerdink, R. B.; Nilessen, W. M. A.; Brinkman, U. A. T. H.; J. Chromatogr. A 2002, 970, 65.

14. Ayano, E.; Kanazawa, H.; Ando, M.; Nishimura, T.; Anal. Chim. Acta 2004, 507, 211.

15. Kodešová, R.; Kočárek, M.; Kodeš, V.; Drábek, O.; Kozák, J.; Hejtmánková, K.; J. Hazard. Mater. 2011, 186, 540.

16. Griffiths, B. S.; Ritz, K.; Bardgett, R. D.; Cook, R.; Christensen, S.; Ekelund, F.; Sørensen, S. J.; Bååth, E.; Bloem, J.; de Ruiter, P. C.; Dolfing, J.; Nicolardot, B.; Oikos 2000, 90, 279.

17. Lane, D. J. In Nucleic Acids Techniques in Bacterial Systematic; Stackebrandt, E.; Goodfellow, M., eds.; John Wiley: New York, 1991, p. 115.

18. Zhang, Q. Y.; Xiao, F.; Xie, J.; Li, Z. Q.; Gui, J. F.; J. Virol. 2004, 78, 6982.

19. Tamura, K.; Peterson, D.; Peterson, N.; Stecher, G.; Nei, M.; Kumar, S.; Mol. Biol. Evol. 2011, 28, 273. 
20. Anastassiades, M.; Lehotay, S.; Stajnbaher, D.; Schenck, F. J.; J. AOAC Int. 2003, 83, 412.

21. Shan, G.; Jin, W.; Lan, E. K. H.; Xing, X.; J. Environ. Sci. 2008, $20,80$.

22. Sterne, M.; Batty, I.; Pathogenic Clostridia; Butterworth Heinemann: London, 1991.

23. Kuramae, E. E.; Yergeau, E.; Wong, L. C.; Pijl, A. S.; van Veen, J. A.; Kowalchuk, G. A.; FEMS Microbiol. Ecol. 2012, 79, 12.

24. Carlin, F.; Food Microbiol. 2011, 28, 177.

25. Langenegg, J.; Doberreiner, J.; Pesqui. Vet. Bras. 1988, 8, 37.

26. Yamamoto, K.; Tamaru, Y; AMB Express 2016, 6, DOI: 10.1186/ s13568-015-0169-5.

27. Bastida, F.; Nicolas, C.; Moreno, J. L.; Hernandez, T.; Garcia, C.; Pedosphere 2010, 20, 479.

28. Lu, J.; Chen, T.; Wua, J.; Wilson, P. C.; Xiangyang, H.; Jiazhong, Q.; Water, Air, Soil Poll. 2011, 223, 3055.

29. Borden, J. R.; Papoutsakis, E. T.; Appl. Environ. Microbiol. 2007, 73, 3061.

30. Hampton, T.; JAMA, J. Am. Med. Assoc. 2004, 291, 1188.

31. Fry, J. C.; Staples, D. G.; Water Res. 1974, 12, 1029.

32. Yoon, M. H.; Im, W. T.; Int. J. Syst. Evol. Microbiol. 2007, 57, 1834.

33. Kampfer, P.; Lodders, N.; Falsen, E.; Int. J. Syst. Evol. Microbiol. 2011, 61, 518.

34. Vial, L.; Chapalain, A.; Groleau, M. C.; Deziél, E.; Environ. Microbiol. 2011, 13, 1.
35. Vogt, C.; Alfreider, A.; Lorbeer, H.; J. Contam. Hydrol. 2004, 68,121

36. Yang, C.; Liu, N.; Guo, X.; Qiao, C.; FEMS Microbiol. Lett. 2006, 265, 118.

37. Boonchan, S.; Britz, M. L.; Stanley, G. A.; Appl. Environ. Microbiol. 2000, 66, 1007.

38. Nishino, S. F.; Paoli, G. C.; Spain, J. C.; Appl. Environ. Microbiol. 2000, 66, 2139.

39. Ribani, M.; Bottoli, C. B. G.; Collins, C. H.; Jardim, I. C. S. F.; Melo, L. F. C.; Quim. Nova 2004, 27, 771.

40. Santana, A. K. M.; Nunes, L. C. C.; Medeiros, F. P. M.; Silva, M. J.; Lavra, Z. M. M.; Rolin-Neto, P. J.; Rev. Cienc. Farm. Basica Apl. 2007, 28, 177.

41. Youden, W. J.; Steiner, E. H.; Statistical Manual of AOAC; Association of Official Analytical Chemistry (AOAC): Washington, 1975.

42. Mata-Sandoval, J. C.; Karns, J.; Torrents, A.; Environ. Sci. Technol. 2002, 36, 4669.

43. Galiulin, R. V.; Rashkin, V. N.; Galiulin, R. A.; Birch, P.; Land Contam. Reclam. 2001, 9, 4.

44. Chowdhury, A.; Prachan, S.; Soho, M.; Sanjal, N.; Indian J. Microbiol. 2008, 48, 114.

45. Beeler, A.; Schlenk, D. K.; Tetrahedron Lett. 2001, 42, 5371.

Submitted: October 27, 2017

Published online: April 2, 2018 